\title{
The Tensions of Technē: On Heidegger and Screendance
}

\author{
Ann Cooper Albright
}

$\mid$ entered the Screendance Network from a slightly oblique angle. On one hand, I was the most unschooled of many of my illustrious colleagues in contemporary examples of screendance, and I certainly was much less addicted to YouTube searching and my computer in general. On the other hand, I came to the table with a curiosity about the historical and theoretical intersections of bodies and machines throughout the twentieth century and a fair dose of feminist film theory. Thus, as people around me chatted about so-and-so's new film, or the latest politics of the latest curator at the latest screenings, I was busy looking out for the ways in which the act of filming dance was implicated in the screened representation and how the ubiquity of screens in contemporary dance affects how we watch movement. That is to say, I have become interested not only in what we are seeing (a particular filmmaker's signature, the long shots, the jump cuts, the choreography, etc.), but in how the very structure of our seeing (both on and off the screen) has been affected by filmic technologies. As we enter the second decade of the twenty-first century, I believe that we must think seriously about the implications of the increasing presence of screens in the dance field as a whole. In other words, how has looking at dance on screen made us look at dance on stage differently?

At first, I must admit that I was a wee-bit put off by what I perceived as the lack of attention to theoretical perspectives in discussions about screendance that I was witnessing in and around the various festivals. But then I began to see that maybe my role in the Screendance Network and The International Journal of Screendance was to call for more intentionality about how screendance helps construct our vision of twenty-first century dancing bodies. There are, of course, multiple tensions between live performance and mediated images, many of which relate to the radically different economies of their respective circulation and exchange. But I believe that these material and conceptual tensions can be very productive if we are willing to examine their interconnectedness. Attention, intention, tension: these words are in the forefront of my mind when I begin to think about the relationship between dance and technology.

In his 1954 treatise, The Question Concerning Technology, philosopher Martin Heidegger connects the terms technology and technique with their etymological root, techne, an ancient Greek concept that refers at once to the skills of the artisan and the visionary power of the artist. Heidegger also links techne to episteme, a way of knowing the world. Thus dance techniques and media technologies are not simply about the capacity of machines (or even the dancer's body-as-machine); they also concern how we come to know the world. For Heidegger, this knowledge is not a passive recognition of what already exists, but rather a method of "bringing forth," a "revealing" of a truth. He writes: 
Thus what is decisive in techne does not lie at all in making and manipulating nor in the using of means, but rather in the aforementioned revealing. It is as revealing, and not as manufacturing, that techne is a bringing-forth [. . .] Technology comes to presence in the realm where revealing and unconcealment takes place, where aletheia, truth, happens.'

Although his philosophical language is incredibly dense, and at times his use of gerunds is delightfully peculiar, what I appreciate in this essay is the idea that technology could render, rather than efface, presence-be it theatrical presence, or a more existential being-in-the-world.

My decision to curate a cluster of short responses to Heidegger's essay was prompted by a discussion in an editorial board meeting last June. There we were brainstorming which historical and theoretical essays might inspire or provoke a cluster of interesting responses. I turned to Heidegger, knowing, of course, that many people react fairly strongly to both his theoretical insights and the legacy of his association with National Socialism in Germany. And yet, despite the awkward fit of history (a lot has happened in the last 57 years) and discipline (philosophy), I felt this essay had helped me to articulate the inherent interconnectedness between dance and technologies, including the ways that dance techniques are, in fact, examples of very effective technologies of the body. Rereading the essay years later, I recognized that even back in the 1950s, Heidegger had thought through how often habit can masquerade as knowledge, as well as the intertwined issues concerning power, desire, and imagination that are embedded within the our relationship to technology. Right at the beginning of his essay, Heidegger elucidates the importance of being intentional about this relationship when he writes:

Thus we shall never experience our relationship to the essence of technology so long as we merely conceive and push forward the technological, put up with it, or evade it. Everywhere we remain unfree and chained to technology, whether we passionately affirm or deny it. But we are delivered over to it in the worst possible way when we regard it as something neutral; for this conception of it, to which today we particularly like to do homage, makes us utterly blind to the essence of technology. ${ }^{2}$

I asked four people who work as artists, screendance makers, and scholars to respond to Heidegger's The Question Concerning Technology from the perspective of their own interests in the field. What follows is a sequence of writings that both speak to Heidegger's essay and each other in unexpected and interesting ways. Prompted by Heidegger's use of etymology to think past the obvious, Ann Dils traces the roots of the words "screen" and "dance." These histories provide a slightly difference perspective on the term screendance which Ann uses as an opportunity to look again at Ghostcatching, a collaboration between Paul Kaiser, Shelley Eshkar, and Bill T. Jones about which she had written over a decade ago. In his essay, "The Sorrow and the Pithy," Kent de Spain provides a trenchant overview of Heidegger's main points, weaving into his analysis a tongue-in-cheek, but also very hopeful, commentary on the problems and possibilities of working in the folds of movement and screens. Lisa Naugle and John Crawford write about their collaboration with Active Space and the ways in which memory and illusion are called forth by their use of the latest interactive technologies. Finally, Tom Lopez channels the ancestral spirits of 
techne and poïesis, two of Heidegger's favorite terms. In Tom's multi-vocal writing, these "twins" are put into dialogue across the divide of time and space, each one commenting and cross-referencing (sometimes contradicting) the other's words. I cannot stop feeling as if Heidegger would be pleased to read these musings sponsored by his essay. I thank my colleagues for taking the time out of their busy lives to share their thoughts on "the tensions of techne."I have no doubt in my mind that the readers will be inspired to continue the dialogue begun on the following pages.

\section{References}

Heidegger, Martin. "The Question Concerning Technology." The Question Concerning Technology and Other Essays. Translated by W. Lovitt. New York: Harper Torchbooks, 1977. 3-35.

\section{Notes}

1. Heidegger, "The Question,"13.

2. Ibid. 4. 